\title{
Pemanfaatan Buah Mangrove Sebagai Sumber Makanan Alternatif di Halmahera Barat, Maluku Utara
}

\author{
JAILAN SAHIL ${ }^{1}$, IRHAM SOAMOLE ${ }^{1}$ \\ ${ }^{1}$ Program Studi Pendidikan Biologi, FKIP Universitas Khairun Ternate \\ Jl. Bandara Baabullah kampus 1 Unkhair Akehuda Kota Ternate Utara 92714 \\ Email : jailan_sahil@yahoo.com
}

\begin{abstract}
This study aims to determine: (1) how the management of mangrove fruit as alternative food ingredients (2) types of mangrove that use by people as alternative food items. The method used in this research is the development of research that displayed products to be produced and can be implemented. The results showed that the process of making mangrove fruit as food begins with boiling mangrove fruit, stripping, immersion with ash, drying and milling into flour. Furthermore, the starch is used as raw material for making dry or wet cake. The organoleptic test used to determine the level of preference or the viability of a product to be accepted by the panelists (consumers) includes flavor, aroma, texture and color. The 30 respondents answered 4 (preferred) and 5 (strongly preferred). This shows that they like the products from these two types of mangrove.
\end{abstract}

Keywords: alternative food, mangrove fruit, North Maluku

\section{PENDAHULUAN}

Hutan mangrove merupakan ekosistem utama pendukung kehidupan di wilayah pesisir dan kelautan. Selain mempunayai fungsi ekologis sebagai penyedia nutrient bagi biota perairan, tempat pemijahan dan usaha (nursery ground) berbagai macam biota, penahan abrasi pantai dari amukan angin taufan dan tsunami serta penyerapan limbah, juga mempunyai fungsi ekonomis yang tinggi misalnya sebagai penyedia bahan bakar, obat-obatan, tempat wisata alam, sebagai objek pendidikan dan latihan maupun pengembangan ilmu pengetahuan lainnya (Saparinto, 2007).

Hutan mangrove hingga saat ini masih dimanfaatkan sebagai penghasil kayu baik untuk kebutuhan bahan baku chip, memenuhi kebutuhan bahan baku arang, tiang pancang dan sebagainya. Selain itu lahan dari hutan mangrove saat ini telah banyak di konversi baik untuk kebutuhan lahan budidaya maupun untuk perumahan, pelabuhan maupun industri. Hal ini bisa terjadi karena kurangnya pemahaman dari masyarakat maupun pengembangan dan pemegang kebijakan tentang fungsi lain dari hutan mangrove (Arief, 2003). Salah satu fungsi hutan mangrove yang masih sedikit sekali diketahui oleh masyarakat umum adalah sumberdaya mangrove sebagai salah satu bahan baku makanan alternatif. Buah mangrove memiliki prospek sangat baik untuk dikembangkan menjadi bahan pangan alternatif berbagai macam resep makan, terutama bagi masyrakat di sekitar pesisir pantai, juga sebagai penyedia karbohidrat maupun sebagai bahan baku industri (Latumahina, 2007).

Ada sebagian masyarakat di Desa Sidangoli Dehe khususnya masyarakat di sekitar pesisir pantai telah mengolah dan mengkonsumsi buah mangrove secara tradisional. Buah mangrove mempunyai kandungan karbohidrat yang sangat tinggi sekaligus rendah lemak. Buah mangrove mengandung air $5,10 \%$, protein $1,10 \%$, lemak $1,70 \%$, karbohidrat $91,60 \%$ dan abu $1,78 \%$ (Nawaty, 2006 dalam Mukaram, 2010).

Di wilayah Provinsi Maluku utara pada umumnya dan Desa Sidangoli Dehe pada khususnya memiliki potensi hutan mangrove yang cukup besar dan tersebar disemua wilayah pesisir, namun umumnya pemanfaatan hutan mangrove hanya terfokus pada kayu bakar, obat-obatan serta konversi lahan menjadi lahan pemukiman, indusrti dan perikanan. Padahal mangrove memiliki prospek sangat baik untuk dikembangkan menjadi bahan pangan alternatif berbagai 
macam resep makanan dan minuman, terutama bagi masyarakat di sekitar pesisir pantai, juga sebagai penyedia karbohidrat maupun sebagai bahan baku industri rumah tangga. Hal ini karena rendahnya penguasaan ilmu pengetahuan dan teknologi di bidang pengelolaan mangrove, sehingga dengan penerapan ilmu pengetahuan dan teknologi produk olahan mangrove dapat meningkatkan keterampilan dan penguasaan teknologi dalam upaya peningkatkan kesejahteraan hidup masyarakat.

Penelitian ini bertujuan untuk mengetahui cara pengelolaan dan kesukaan buah mangrove oleh masyarakat sebagai bahan makanan alternatif.

\section{METODE}

Penelitian ini dilakukan di Desa Sidangoli Dehe Kecamatan Jailolo Kabupaten Halmahera Barat dar bulan Februari hingga April 2012. Langkah awal dalam penelitian ini adalah melakukan survei untuk mengetahui jenis-jenis mangrove yang tumbuh di Desa Sidangoli Dehe Kecamatan Jailolo Selatan Kabupaten Halmahera Barat. Hasil identifikasi mangrove yang telah dilakukan selanjutnya diambil 2 jenis buah mangrove yaitu $S$. alba dan $R$. stylosa. Buah mangrove diperoleh dengan cara dipetik langsung maupun menggunakan galah. Buah yang dipetik dengan ciri sudah matang yaitu warna buah hijau tua dengan kotiledon berwarna kuning untuk jenis $R$. stylosa (400 buah) dan jenis $S$. alba ditandai dengan warna hijau tua kecoklatan (250 buah). Buah yang sudah dikumpulkan selanjutnya diolah menjadi tepung. (Santoso, dkk, 2005).

Dari jenis mangrove yang ditemukan, yang dijadikan sampel adalah jenis $R$. stylossa dan $S$. alba . Pengolahan dengan menggunakan perendaman abu gosok atau abu dapur (soda ash) adalah salah satu cara yang dapat dilakukan karena abu gosok tersebut dapat menghambat laju oksidasi racun dan menetralkan asam yang bersifat karsinogenik pada bahan tersebut (Pembayun, 2000).

Uji organoleptik dilakukan untuk mengetahui tingkat kesukaan atau kelayakan suatu produk agar dapat diterima oleh penulis (konsumen). Metode pengujian yang dilakuakan adalah metode hedonik (uji kesukaan) meliputi: warna, aroma, tekstur dan rasa dari produk yang dihasilkan (Rampengan dkk.,1985) Dalam metode hedonik ini panelis diminta memberikan penilaian berdasarkan tingkat kesukaan. Skor yang digunakan adalah 5 (sangat suka), 4 (suka), 3 (agak suka), 2 (tidak suka), 1 (sangat tidak suka).

Pengumpulan data dilakukan setelah produk tepung olahan buah mangrove selesai di proses dan dilakukan validasi produk meliputi tingkat kualitas produk dan tingkat kesukaan produk yang dilakukan dengan angket organoleptik.

Analisis data dilakukan setelah mengumpulkan data yaitu setelah di uji cobakan produk dengan meminta tanggapan dari responden. Dengan menggunakan langkah-langkah sebagai berikut:

1) Menghitung nilai prosentasi data dengan menggunakan formulasi rumus sebagai berikut:

$$
\mathrm{P}=\frac{\Sigma_{\mathrm{x}}}{\Sigma_{\mathrm{xi}}} \times 100 \%
$$

Keterangan:

$\mathrm{P} \quad$ : Prosentasi

$\sum \mathrm{x} \quad$ : Jumlah jawaban penilaian

$\sum x i$ : Jumlah jawaban tertinggi

2) Setelah nilai prosentase di peroleh maka di tafsirkan dalam kalimat sebagaimana dikemukakan oleh Arikunto (2006)

Tabel 1.Nilai Prosentase dan Kriteria Validasi

\begin{tabular}{cc}
\hline Prosentasi & Kriteria validasi \\
\hline $76-100$ & Disukai \\
\hline $56-75$ & Cukup disukai \\
\hline $40-55$ & Kurang disukai \\
\hline $0-30$ & Tidak disukai \\
\hline
\end{tabular}


HASIL

Dari hasil olahan buah mangrove tersebut menjadi tepung mangrove dan produk makanan dalam bentuk kue. Kemudian dari hasil olahan tersebut dilakukan uji

organoleptik baik tepung maunpun hasil produk dengan responden berjumlah 30 orang. Data hasil uji organoleptik dapat dilihat pada Tabel 1 dan 2 berikut ini.

Tabel 1. Hasil analisis uji organoleptik untuk jenis mangrove $R$. stylosa

\begin{tabular}{llcccccc}
\hline \multirow{2}{*}{ No Uji Organoleptik } & \multicolumn{5}{c}{ Skor Jawaban } \\
\cline { 3 - 7 } & & & 5 & 4 & 3 & 2 & 1 \\
\hline 1 & Warna & $3 \%$ & $97 \%$ & - & - & - \\
\hline 2 & Tekstur & $3 \%$ & $97 \%$ & - & - & - \\
\hline 3 & Aroma & $75 \%$ & $25 \%$ & - & - & - \\
\hline 4 & Rasa & $46 \%$ & $54 \%$ & - & - & - \\
\hline
\end{tabular}

Tabel 2. Hasil analisis uji organoleptik untuk S. alba

\begin{tabular}{|c|c|c|c|c|c|c|}
\hline \multirow[t]{2}{*}{ No } & \multirow[t]{2}{*}{ Uji Organoleptik } & \multicolumn{5}{|c|}{ Skor Jawaban } \\
\hline & & 5 & 4 & 3 & 2 & 1 \\
\hline 1 & Warna & $3 \%$ & $97 \%$ & - & - & - \\
\hline 2 & Tekstur & $3 \%$ & $97 \%$ & - & - & - \\
\hline 3 & Aroma & $73 \%$ & $27 \%$ & - & - & - \\
\hline 4 & Rasa & $46 \%$ & $54 \%$ & - & - & - \\
\hline
\end{tabular}

Keterangan :

$5=$ Sangat disukai

$4=$ Disukai

$3=$ Agak disukai

$2=$ Tidak disukai

$1=$ Sangat tidak disukai

\section{PEMBAHASAN}

Hasil penelitian dengan menggunakan uji organoleptik yang terdiri dari 30 responden menunjukkan bahwa mereka menyukai hasil olahan dari buah mangrove baik tepung maupun produk dalam betuk kue. Uji organoleptik ini berjuan untuk mengetahui tingkat kesukaan atau kelayakan suatu produk agar dapat diterima oleh panelis (konsumen). Metode pengujian yang dilakuakan adalah metode hedonik (uji kesukaan) meliputi: warna, aroma, tekstur dan rasa dari produk yang dihasilkan (Rampengan dkk.,1985). Setelah dilakukan Uji organoleptik dan di analisis jawaban dari 30 responden, rata-rata mereka menjawab 4 (disukai) dan 5 (sangat disukai). Hal menunjukkan bahwa mereka menyukai hasil produk dari kedua jenis mengrove tersebut baik warna, aroma, tekstur dan rasa serta layak digunakan sebagai sumber makanan.

Menurut Nawaty (2006) dalam Mukaram (2010) buah mangrove mempunyai kandungan gizi yang cukup tinggi dan cocok dikonsumsi sebagai sumber energi. Hal ini disebabkan karena buah mangrove mempunyai kandungan karbohidrat yang sangat inggi sekaligus rendah lemak. Buah mangrove mengandung air $5,10 \%$, protein $1,10 \%$, lemak $1,70 \%$, karbohidrat $91,60 \%$ dan abu 1,78\%. Buah mangrove memiliki manfaat (Santoso dkk, 2005) yaitu:

1. Sebagai makanan pokok masyarakat asli Papua yang bermukim di sekitar pesisir pantai.

2. Tepung sebagai bahan baku pembuatan kue kering atau basah.

3. Berbagai aneka kue seperti dodol, wajik, talang, onde-onde, bola asam, donat, dan bolu.

4. Sirup dan jus

5. Manisan dan keripik manis

6. Makan bapau, dadar, lumpia, bubur

7. Obat pembasmi hama kubis

8. Menambah kadar alcohol pada minuman keras 
Menurut hasil penelitian yang dilakukan oleh IPB pada tahun 2005 bekerjasama dengan Badan Bimas Nusa Tenggara Timur dikatakan bahwa kandungan energi buah mangrove adalah 371 kalori per 100 gram, lebih tinggi dari beras (360 kalori per 100 gram), dan jagung (307 kalori per 100 gram). Kandungan karbohidrat buah bakau sebesar 85.1 gram per 100 gram, lebih tinggi dari beras (78.9 gram per 100 gram) dan jagung (63.6 gram per 100 gram) .

Jenis-jenis mangrove yang buahnya dapat dijadikan sebagai bahan baku makanan yaitu: $A$. aureum, A. marina, $N$. fructicans, $R$. mucronata, $R$. stylosa, $R$. apiculata, dan, $S$. alba (Santoso dkk., 2005). Jenis mangrove $S$. alba merupakan tumbuhan jenis pioner di zona depan. Buah S. alba tidak mengandung racun (toksin) dan langsung dapat dikonsumsi (dimakan). Buah yang sudah masak terasa asam dan tidak memerlukan perlakuan atau langsung dapat dimasak menjadi aneka makanan atau minuman (Santoso dkk, 2005).

Proses pengelolahan buah mangrove sebagai bahan makanan untuk jenis $S$ alba yaitu:

1. Buah yang masih segar di rebus selama 30 menit dan selanjutnya di kupas

2. Direndam dengan abu dapur untuk menghilangkan racun.

3. Setiap hari air dengan abu dapur diganti pada jam yang sama yaitu direndam pada jam 8 pagi hari pertama dan diganti air dan abu pada jam 8 hari kedua prosesnya selama 3 hari.

4. Setelah air rendaman rasanya sudah tawar, selanjutnya buah mangrove tersebut di jemur sampai kering,

5. Kemudian digiling dan diayak menjadi tepung

6. Setelah itu tepung dari buah mangrove tersebut digunakan sebagai bahan dasar untuk pembuatan kue kering atau basah.

Jenis $R$. tylosa merupakan salah satu jenis mangrove dari marga Rhizoporaceae yang umumnya tumbuh di zona depan. Buah manrgrove jenis ini sudah dimanfaatkan oleh masyarakat Bulukumba Sulawesi Selatan dan masyarakat Papua sebagai bahan baku dalam pembuatan aibon. Namun buah jenis ini bersifat racun jadi perlu adanya penanganan khusus (Santoso dkk, 2005).

Kendala yang dihadapi dalam pembuatan tepung mangrove $R$. stylosa ini adalah terdapatnya racun yang ada pada buah mangrove tersebut. Racun ini dapat menyebabkan rasa pahit pada bahan dan keracunan seperti pusing, mual dan muntah. Diduga racun yang ada adalah tanin dan sianida. Selain itu terdapat bau langu pada pembuatan tepung, ini disebabkan karena enzim lipoksigenase yang ada pada bahan Mulyani (1990) dalam Mohson (2006). Pengolahan dengan menggunakan perendaman abu gosok atau abu dapur (soda ash) adalah salah satu cara yang dapat dilakukan. Karena abu gosok dapat menghambat laju oksidasi racun dan menetralkan asam yang bersifat karsinogenik pada bahan tersebut dan telah terbukti pada gadung (Pembayun, 2000). Lanjut wirjatmadi (2005) menambahkan bahwa kadar sianida dapat dihilangkan dengan pencucian, perendaman, perebusan dan penjemuran. Oleh sebab itu, penurunan kandungan sianida pada produk tepung singkong dikarenakan terjadi penguapan sianida bebas saat proses pengeringan dengan menggunakan pengering pada suhu $70^{\circ} \mathrm{C}$.

Semakin berkembangnya teknologi pangan, maka produksi tepung gandum semakin hari semakin berkurang. Salah satu cara dalam mengatasi kendala tersebut adalah menjadikan buah tumbuhan mangrove $R$. stylosa menjadi tepung. Tepung mangrove jenis ini digunakan sebagai salah satu alternatif untuk mengurangi pemakaian tepung terigu serta dapat diaplikasikan sebagai bahan substitusi pada pengolahan produk-produk seperti biskuit, crackers dan produk pangan lainnya sehingga dapat meningkatkan penganekaragaman pangan.

Pengolahan untuk menghilangkan racun selama ini dilakukan adalah dengan melakukan beberapa metode seperti pemanasan, perendaman dengan larutan garam dan penggunaan abu dapur. Pemanasan selama 3 jam dan perendaman dengan abu khususnya abu sekam dapat menurunkan sianida pada bahan karena abu sekam mempunyai 
kemampuan menyerap cairan sel dalam jaringan dan bahan beracun keluar dari umbi, sehingga mempermudah keluarnya alkaloid dioskorin pada bahan gadung (Mulyani, 1990).

Proses pengelolahan buah mangrove sebagai bahan makanan untuk jenis $R$. stylosa yaitu:

1. Buah yang sudah tua/masak direbus selama 3 jam

2. Selanjutnya di kupas

3. Direndam dengan abu dapur untuk menghilangkan racun.

4. Setiap hari air dengan abu dapur diganti pada jam yang sama yaitu direndam pada jam 8 pagi hari pertama dan diganti air dan abu pada jam 8 hari kedua prosesnya selama 3 hari.

5. Setelah air rendaman rasanya sudah tawar, selanjutnya buah mangrove tersebut di jemur sampai kering,

6. Kemudian digiling dan diayak menjadi tepung

7. Setelah itu tepung dari buah mangrove tersebut digunakan sebagai bahan dasar untuk pembuatan kue kering atau basah.

\section{KESIMPULAN}

1. Proses pengelolaan buah mangrove sebagai sumber makanan terdiri dari 5 tahap yaitu perebusan buah mangrove, pengupasan kulit, perendaman dengan air, penjemuran dan dihaluskan menjadi tepung. Selanjutnya digunakan sebagai bahan dasar dalam pembuatan makanan.

2. Setelah dilakukan Uji organoleptik untuk mengetahui tingkat kesukaan atau kelayakan suatu produk agar dapat diterima oleh penelis (konsumen) yang meliputi rasa, aroma,tekstur dan warna ternyata dari 30 responden rata-rata mereka menjawab 4 (disukai) dan 5 (sangat disukai). Hal ini menunjukkan bahwa mereka menyukai hasil produk dari kedua jenis mengrove tersebut.

\section{DAFTAR PUSTAKA}

Arief A. 2003. Hutan Mangrove Fungsi dan Manfaatnya. Yogyakarta: Penerbit Kanisius.
Bandaranayake WM. 2002. Bioactivities, Bioactive Compounds and Chemical Constituents of Mangrove Plants. AIMS Research. http:// www.aims.go.au/. Diakses Januari 2013

Bengen DG. 2000. Teknis Pengambilan Conton Dan Analisi Data Biofisik Sumberdaya Pesisir. Bogor: Pusat kajian sumberdaya pesisir dan lautan, Institut Pertanian Bogor.

Bengen DG. 2002. Sinopsis Ekosistem dan Sumber Daya Alam Pesisir dan Laut. Pusat Kajian Sumber Daya Pesisir dan Lautan. Bogor: Pusat kajian sumberdaya pesisir dan lautan, Institut Pertanian Bogor.

Dahuri R., Rais J, Ginting SP dan Sitepu MJ, 2001. Pengelolaan Sumberdaya Wilayah Pesisir dan Lautan Secara Terpadu. Jakarta: PT. Pradnya Pramita.

Fortuna JD, 2005. Buah Bakau Sebagai Makanan Pokok. http://www. Tempointeraktif.com. Diakses Januari 2013

Gunarto. 2004. Konservasi Mangrove Sebagai Pendukung Sumber Hayati Perikanan Pantai. Jurnal Litbang Pertanian. vol 23 (1): $15-21$.

Haryono T. 2004. Keripik Buah Mangrove, Upaya Melestarikan Hutan. Kompas, Selasa 5 Oktober 2004.

Latumahina A. 2007. Inovasi dari Buah Mangrove. [Tesis]. Manado: Program Pascasarjana Program Studi Ilmu Perairan Universita Sam Ratulangi.

Mamoribo. 2003. Salah Satu Manfaat Mangrove (Bakau) Bagi Manusia, Potensi Buah Mangrove Sebagai Alternatif Sumber Pangan Indonesia. Kompas, Selasa 5 Oktober 2004.

Mukaram R. 2010. Optimalisai Produk Olahan Buah Mangrove Sebagai Bahan Makanan. Ternate: Universitas Khairun Ternate.

Noor YR, Khazali M, dan Suryadiputra INN. 1999. Panduan Pengenalan Mangrove di Indonesia. Bogor: PKA/WI-IP.

Pramudya B. 2004. Strategi Diversifikasi Pangan. Simposium Nasional V Hak Kekayaan Intelektual dan Standarisasi, 28 
September 2004. Semarang: Kerjasama RISTEK dan Universitas Diponegoro.

Pramuji. 2000. Hutan Mangrove di Indonesia: Peranan Permasalahan dan Pengolaan. Osean. vol XXV (1):1.

Pembayun R. 2000. Hydro Cyanic Acid and Organoleptic Test on Gaddung InstantRice from Various Methods of Detcsification. Prosiding Seminar Nasional Industri Pangan. vol 13:97-107.

Petruccioli ML, Brimer AR, Plomp CAT. 1997. Educational Design: Introduction. from Tjeerd Plomp (eds). Educational \& Training System Design: Introduction. Design of Education and Training (in Dutch). Utrecht (the Netherlands): Faculty of Educational Science and Technology, University of Twente. http://blog.unnes.ac.id/. Diakses Januari 2013

Rampengan VJ, Pontoh dan Sembel DT. 1985. Dasar-dasar Pengawasan Mutu Pangan. Makassar: Badan Kerjasama Perguruan Tinggi Negeri Indonesia Bagian Timur.

Saparinto C. 2007. Pendayagunaan Ekosistem Mangrove. Semarang: Penerbit Dahara Prize.
Santoso N, Nurcahya BD, dan Siregar IF. 2005. Resep Makanan Berbahan Baku Mangrove Dan Pemanfaatan Nipah. Jakarta: Lembaga Pengkajian dan Pengembangan Mangrove.

Sadana D. 2007. Buah Aibon di Bsiak Timur Mengandung Karbohidrat Tinggi. Biak: Situs Resmi Pemda Biak.

Supriharyono. 2006. Konservasi Sumberdaya Hayati di Wilayah Pesisir dan Laut Tropis. Yogyakarta: Pustaka pelajar.

Sugiarto dan W. Ekarianto. 1996. Penghijauan Pantai. Jakarta: Penerbit Swadaya.

Sukaryanto A. 2006. Pertahankan Hutan Mangrove di Laguna. Suara Merdeka, 18 Juli 2006.

Widowati S, Sukarno L, Suarni dan Komalasari O. 2003. Labu Kuning: Kegunaan dan Proses Pembuatan Tepung. Prosiding Seminar Nasional \& Pertemuan Tahunan Perhimpunan Ahli Teknologi Pangan Indonesia (PATPI), 2223 Juli 2003. Yogyakarta: PATPI.

Wirjatmadi B. 2005 Pengaruh Beberapa Perlakuan Terhadap Penurunan Kadar HCN Pada Ubi Kayu (Maniholes culenta Crantz). Surabaya: Universitas Airlangga. 